\title{
INTERNATIONAL STANDARDS ON COMBATING MONEY LAUNDERING AND CORRUPTION CRIMES: SOME ASPECTS OF INVESTIGATIONS
}

\author{
Ganna Gorbenko ${ }^{1}$ \\ ${ }^{I}$ Graduate student of administrative law and administrative procedure department, National Academy of \\ Internal Affairs, Ukraine, e-mail: gorbenkogannal@gmail.com
}

\begin{abstract}
The article analyzes international standards on combating money laundering and corruption crimes. The evolution of The FATF Standards, which have been revised to strengthen global safeguards and further protect the integrity of the financial system by providing governments with stronger tools to take action against financial crime, has been investigated. At the same time, these new standards address new priority areas such as corruption and tax crimes. The aim of the article is to compare international legal acts that regulate the field of anti-money laundering and anti-corruption. The research methodology: the functional and analytical methods of comparative legal research were used as the most appropriate. In comparison with AML/CFT law, the international legal requirements regarding anti-corruption compliance are very general. Many countries do not have laws and regulations on anti-corruption compliance. Companies develop their compliance programmes based on international law, foreign law that has transnational application. Certain provisions of the above-mentioned international legal acts, in addition to their scope, regulate the investigation of crimes related to money laundering, terrorist financing and corruption crimes. The main results: the implementation of international standards in national law in some way unifies the approaches to the investigation of complex crimes, which are often combined in a scheme, and allows the introduction of effective methods of investigating such crimes.
\end{abstract}

Keywords: anti-money laundering laws, anti-money laundering acts, investigations, financial investigation, suspicious transaction report, United Nations Convention against Corruption (UNCAC), USA Patriot Act, UK Bribery Act, national anti-money laundering legislation, national anti-corruption legislation, FATF Recommendations.

JEL Classification: D30, D73, D78

Formulas: 0; fig.: 0; tabl.: 0; bibl.: 27.

Introduction. Recent academic studies and reports from international organizations and groups illustrate the close connections between corruption and moneylaundering [7, p.28-29]. Corrupt officials often have to legalize criminal proceeds because of the close scrutiny over their incomes, assets, and significant purchases $[8$, p. 6]. In some cases, criminals plan the receipt of a bribe and the laundering of this money in the framework of one scheme. The same shadow financial infrastructure has been used for payments between participants in a corrupt scheme and for the legalization of criminal proceeds. Under international law, there is a clear linkage between corruption and moneylaundering.

The United Nations Convention against Corruption [9, p.17] established obligations for States Parties to criminalize the laundering of proceeds of corruption offences and to take measures to prevent corruption. The International standards on 
combating moneylaundering, the financing of terrorism, and proliferation [10, p.7] stipulate that corruption and bribery should be covered as predicate offences.

Aims. The aim of the article is to compare international legal acts that regulate the field of anti-money laundering and anti-corruption.

Methods. Functional and analytical methods of comparative legal research were used as the most appropriate. These methods allowed the author to examine international law and other regulations for similarities and differences between antimoney laundering and anti-terrorist financing legislation and anti-corruption legislation. Sources of research include international conventions, international law, reports and other documents of international intergovernmental and nongovernmental organizations, national legislation and scientific publications [11, p.2829]. Specific ideas and opinions are also based on the author's many years of practical experience in this field. This includes work in the Ukrainian Financial Intelligence Unit (FIU) and anti-corruption bodies, as well as training for law enforcement professionals and law enforcement officers from various jurisdictions. The purpose of the study is to identify existing problems in regulating anti-corruption legislation and possible ways to solve them.

Results. So let's consider the provisions of the main regulations that were first adopted in some jurisdictions, and due to the effective action of some of their provisions, the scope has been extended to other jurisdictions in the form of international legal acts.

Bank Secrecy Act adopted in 1970 established requirements for recordkeeping and reporting by private individuals, banks and other financial institutions. This act was designed to help identify the source, volume, and movement of currency and other monetary instruments transported or transmitted into or out of the United States or deposited in financial institutions

It required banks to (1) report cash transactions over $\$ 10,000$ using the Currency Transaction Report; (2) properly identify persons conducting transactions; and (3) maintain a paper trail by keeping appropriate records of financial transactions [12].

The Bank Secrecy Act (BSA), 31 USC 5311 et seq., sets out requirements for programs, record keeping, and reporting for national banks, federal savings associations, federal affiliates, and foreign banking institutions.

The BSA was subsequently amended to reflect the provisions of the USA PATRIOT Act, which requires each bank to adopt a customer identification program as part of its BSA compliance program. In addition to using information provided by banks to investigate money laundering and terrorist financing, US law enforcement agencies also provide banks with access to resources and tools that can be used to strengthen BSA / AML risk management programs. [13]

In 1977, in order to make it illegal for certain classes of individuals and legal entities to make payments to foreign government officials to assist in obtaining or maintaining a business, the Foreign Corruption Act ("FCPA") was passed, as amended, 15 U.S.C. $\S \S 78 \mathrm{dd}-1$ and others. 
Specifically, the anti-bribery provisions of the FCPA prohibit the willful use of the mails or any means of instrumentality of interstate commerce corruptly in furtherance of any offer, payment, promise to pay, or authorization of the payment of money or anything of value to any person, while knowing that all or a portion of such money or thing of value will be offered, given or promised, directly or indirectly, to a foreign official to influence the foreign official in his or her official capacity, induce the foreign official to do or omit to do an act in violation of his or her lawful duty, or to secure any improper advantage in order to assist in obtaining or retaining business for or with, or directing business to, any person. [5]

Thus, the requirements of the FCPA clearly define the conditions for proper accounting and make it easy to navigate in reporting documents through a standardized approach and unification of reporting.

40 recommendations of the Financial Operations Working Group (FATF) (1990, last revision in 2016): the FATF recommendations provide a comprehensive and coherent system of measures to be implemented by countries to combat money laundering and terrorist financing, as well as the financing of the proliferation of weapons of mass destruction. Countries have different structures of legal, administrative and operational systems and different financial systems, and therefore not all can take identical measures to address these threats. Thus, the FATF Recommendations set international standards that countries must implement through measures tailored to specific circumstances. The FATF Recommendations set out the basic measures that countries should take to:

- risk identification and policy development and coordination at the national level;

- prosecution of money laundering, terrorist financing and financing the proliferation of weapons of mass destruction;

- application of safeguards for the financial sector and other identified sectors;

- establishing the powers and responsibilities of the competent authorities (e.g. investigative, law enforcement and supervisory authorities) and other institutional arrangements;

- increasing the transparency and accessibility of information on beneficial ownership of legal entities;

- as well as promoting international cooperation. [14, p.11]

Significant impact on the effectiveness of the country's AML /CFT measures includes the sophistication and complexity of the regulatory and supervisory regime in the country; the level of corruption and the impact of anti-corruption measures; or the level of financial exemptions. Such factors may affect the risks of AML/CFT and increase or decrease the effectiveness of AML/CFT measures. [14, p.14]

Thus, in this context, the effectiveness of the fight against money laundering and terrorist financing is closely linked to the general level of crime in society.

According to the FATF Recommendations, countries must ensure that designated law enforcement agencies are responsible for investigating money 
laundering and terrorist financing within the framework of national anti-money laundering and anti-terrorist financing policies. In all cases involving major revenuegenerating crimes, these designated law enforcement agencies should, on their own initiative, conduct a parallel investigation into the prosecution of money laundering, predicate offenses and terrorist financing. This should include cases where a related predicate offense is committed outside their jurisdiction. Countries should ensure that their competent authorities are responsible for the prompt identification, monitoring and initiation of action to freeze and confiscate property that is, may be, or is suspected of being criminal proceeds. Where appropriate, countries should also use permanent or temporary multidisciplinary teams that specialize in financial or asset investigations. Where appropriate, countries should ensure that joint investigations are conducted with the relevant competent authorities of foreign countries. [14, p.140]

Anti-corruption authorities are empowered to investigate money laundering and terrorist financing offenses or related to corruption offenses in accordance with FATF Recommendation 30, and should have sufficient authority to detect, monitor and initiate the freezing and seizure of assets.

"USA Patriot Act" (full title: Uniting and Strengthening America by Providing Appropriate Tools Required to Intercept and Obstruct Terrorism Act of 2001) terrorism "2001") - a federal law passed in the United States in October 2001, gave the government and police broad powers to oversee citizens. [15]

It was adopted after the terrorist attack of September 11, 2001. The law, in particular, expanded the FBI's rights to eavesdrop and electronic surveillance, which many saw as a violation of the Fourth Amendment to the US Constitution. The rationale for this act was the implementation of the principle that in order to effectively combat crime, it is necessary to make the potential gain from committing a crime less than the potential damage from punishment. This primarily concerns the deprivation of criminals of proceeds from crime.[16]

Since 2015, law enforcement powers to collect information have been somewhat limited (Instead of US Patriot Act now US Freedom Act is in force) - now surveillance is possible only with the court decision. The right to monitor and collect information introduced in Ukraine on the same principle.

Today, the main global document regulating the prevention, investigation and prosecution of corruption and the suspension of operations (freezing), arrest, confiscation and recovery of proceeds of crime is the UN Convention against Corruption, adopted at the 58th session of the UN General Assembly in October 2003, which established the theoretical basis for the adaptation of national legislation and defined the fundamental principles of anti-corruption policy of the member states of this international treaty.

The beginning of the development of international legal regulation in the field of anti-corruption can be considered the adoption on 15 December 1975 of UN General Assembly Resolution 3514 (XXX). The document calls on the governments of all 
countries to take the necessary measures at the national level to prevent and combat corruption, which they deem appropriate, including legislation.

The tasks set by the resolution are clarified and detailed in various documents adopted within the UN. In particular:

- UN General Assembly resolution on combating corruption of 12 December 1996 (A / RES / 51/59); [17]

- UN Declaration against Corruption and Bribery in International Commercial Transactions (1996); [18]

- Guidelines for the effective implementation of the Code of Conduct for Law Enforcement Officials (1989); [19]

- The International Code of Conduct for Public Officials (1996) contains recommendations that public officials must comply with in order to perform their duties properly. [20]

These documents are of a recommendatory nature, but they have played a key role in the preparation of international legal acts that have established international standards for preventing and combating corruption.

According to the Article 30 of UNCAC: "Each State Party shall make the commission of an offence established in accordance with this Convention liable to sanctions that take into account the gravity of that offence. Each State Party shall take such measures as may be necessary to establish or maintain, in accordance with its legal system and constitutional principles, an appropriate balance between any immunities or jurisdictional privileges accorded to its public officials for the performance of their functions and the possibility, when necessary, of effectively investigating, prosecuting and adjudicating offences established in accordance with this Convention." [3, p.23]

In order to combat corruption effectively, each State Party shall, to the extent permitted by the basic principles of its domestic legal system and in accordance with the conditions prescribed by its domestic law, take such measures as may be necessary, within its means, to allow for the appropriate use by its competent authorities of controlled delivery and, where it deems appropriate, other special investigative techniques, such as electronic or other forms of surveillance and undercover operations, within its territory, and to allow for the admissibility in court of evidence derived there from. (Article 50 UNCAC) [3, p.41]

According to the Article 53 of UNCAC each State Party shall, in accordance with its domestic law: take such measures as may be necessary to permit another State Party to initiate civil action in its courts to establish title to or ownership of property acquired through the commission of an offence established in accordance with this Convention; take such measures as may be necessary to permit its courts to order those who have committed offences established in accordance with this Convention to pay compensation or damages to another State Party that has been harmed by such offences; and take such measures as may be necessary to permit its courts or competent authorities, when having to decide on confiscation, to 
recognize another State Party's claim as a legitimate owner of property acquired through the commission of an offence established in accordance with this Convention. [3, p.43]

The most important steps of the Council of Europe in the fight against corruption should be the development of modern anti-corruption standards, European anti-corruption conventions and the establishment of a specialized body for monitoring anti-corruption standards in Council of Europe member states - GRECO.

These are, in particular, the Criminal Law Convention on Corruption [21], the Civil Law Convention on Corruption [22] and the Additional Protocol to the Criminal Law Convention on Corruption [23].

The Criminal Law Convention on Corruption is a key international legal instrument of the Council of Europe, which defines the grounds for criminalization of corrupt practices, the list of them, the types and scope of international legal assistance, as well as international control measures.

The purpose of the Civil Convention against Corruption is to introduce effective means of "legal protection of persons harmed by acts of corruption, to enable such persons to defend their rights and interests, including the possibility of obtaining compensation for the damage caused." [21]

As of April 1, 2013, financial institutions must use the BSA Electronic Reporting System "On Bank Secrecy" to report suspicious activity. Under the Bank Secrecy Act (BSA), financial institutions are required to assist U.S. government agencies in detecting and preventing money laundering, such as:

- keep records of cash purchases of negotiable instruments,

- file reports of cash transactions exceeding \$10,000 (daily aggregate amount), and

- report suspicious activity that might signal criminal activity (e.g., money laundering, tax evasion)

An amendment to the BSA incorporates provisions of the USA Patriot Act, which requires every bank to adopt a customer identification program as part of its BSA compliance program. [13]

As already mentioned, almost all countries have adopted national laws on combating money laundering and terrorist financing. Financial institutions and certain non-financial enterprises and professions have mandatory obligations to implement anti-money laundering and anti-terrorist financing systems that fully comply with these laws. In contrast, many countries do not have national laws and regulations that set formal requirements for compliance with anti-corruption standards. In such jurisdictions, the FCPA and the UK Bribery Act effectively replace national law, and companies develop anti-corruption programs under the influence of these laws and in accordance with them, together with the rules and guidelines adopted by the US and / or UK authorities. 
Corruption risks are an additional factor that encourages the integration of FCPA requirements into anti-corruption programs. But such programs do not always take into account the national and local specifics of different countries. [25]

The lack of national laws and regulations on compliance with anti-corruption requirements raises two problems. Anti-corruption acts developed solely in accordance with foreign standards or copied from foreign law may not always be sufficient for a particular country. Statistics show a very active use of FCPA [26] and the UK Bribery Act to companies from different countries and industries. A recent report by the Anti-Corruption Committee of the International Bar Association (IBA) confirmed the risk of numerous legal actions and stressed the need to discuss conflicts between jurisdictions. [27, p.26]

In Ukrainian legislation, due to the "approximate copying" of norms from foreign regulations and in order to selectively bring into line with international standards of individual national legislation, there are still inconsistencies in national regulations, which causes problems with both the definition and with the investigation of crimes.

For example, in the Law on Combating Money Laundering and Terrorist Financing, the definition of PEP includes senior civil servants [14, p. 4-5], while in compliance with anti-corruption rules, companies pay special attention to relations with any civil servants. Moreover, the definition of a public official varies from country to country. The catalog of risks in the fight against money laundering and terrorist financing is much broader than in compliance with anti-corruption norms, as the regulation of anti-money laundering and terrorist financing is aimed at preventing and combating money laundering. However, corruption is a money laundering offense. As a result, the association of the user or beneficial owner with a jurisdiction with a high level of corruption is usually included in the AML / CFT risk catalogs.

Detection of suspicious transactions is probably not a top priority of anticorruption standards, as is the case with AML/CFT. However, careful analysis of financial transactions can also be an effective way to prevent corruption. The scope of reporting obligations on compliance with anti-corruption rules depends on the country's legal provisions. National criminal law may impose an obligation to report corruption offenses involving serious or organized crime or by providing for a certain threshold of imprisonment as a liability. In other cases, disclosure depends on anticorruption policy. In accordance with anti-money laundering and anti-terrorist financing rules, financial institutions and certain non-financial enterprises and professions are required to report controlled transactions in accordance with national law and to report suspicious transactions identified in the anti-money laundering and anti-terrorist financing program. Thus, both types of compliance involve a combination of binding reporting obligations and discretionary reporting. The similarities described above in compliance programs provide an opportunity for cooperation between law enforcement officers or units responsible for combating money laundering and terrorist financing and combating corruption. [1, p.17-18] 
International standards have greatly influenced the rules and procedures for investigating money laundering and terrorist financing crimes. According to the latest revised recommendations of the FATF, the investigation of such crimes requires cooperation from law enforcement agencies. Motivation of law enforcement agencies to conduct investigations involves, in particular, optimization of organizational and functional structure, namely:

- study of European experience in improving the skills and professional skills of law enforcement personnel;

- increasing the analytical resources of law enforcement agencies by establishing an efficient and timely exchange of information, expanding the use of information solutions, methods of analysis and processing of data sets, systems of analysis and risk management;

- review of approaches to the system of personnel selection, development of knowledge, skills and abilities of employees, their stimulation and encouragement to honest and proactive performance of duties, based on the best world practices;

- elimination of duplication of functions related to combating economic crimes.

So, the key tasks of the investigation are:

- detection of criminal proceeds, search for assets and application of the procedure of confiscation of assets using security measures, such as suspension / arrest (if there are grounds), including:

- establishing the origin of funds or other assets received from or related to illegal activities;

- tracking the movement of cash or other assets related to illegal activities;

- establishing the location, relocation, change of form (transformation) of assets, as well as the acquisition, possession or use of funds or other assets obtained as a result of committing a socially dangerous illegal act;

- establishment of assets for future confiscation.

- initiating pre-trial investigations in criminal proceedings for money laundering (if there are grounds), in particular: establishing methods of concealment or disguise of illegal origin of funds or other assets, disclosure of financial and economic organized structures, undermining transnational criminal ties and obtaining information on types and nature criminal schemes; identification of persons who own such funds, assets or rights to such funds or assets.[10]

Given the growing risk of organized crime entering the economy, financial investigation is an important tool for a modern and effective response to criminal threats, including terrorist financing.

It can provide new evidence of criminal activity, prosecute entire criminal networks, including their transnational consequences, and is key in developing preventive and proactive action through the development of detection and control tools. 
Financial investigation has a preventive and preventive added value. It is an important tool for detecting money laundering, terrorist financing and other serious crimes. It can be used against all criminal markets.

In many cases, financial investigations are needed to develop evidence against high-level sophisticated criminals in order to deactivate transnational and organized criminal networks. Financial investigations can also facilitate national risk assessment in the relevant jurisdiction, as it provides knowledge about the structures of crime.

Its benefits are evident in facilitating the investigation of criminal cases against all serious and organized criminals by:

- defining motives, associations and connections with people and places;

- identify the use of other services, such as telephones, transport and facilities that are relevant to the case;

- search or identification of suspects, witnesses or victims;

- providing information on the movement of the suspect (active, covert use of financial information);

- providing information to address the problem of fruitful and priority offenders, when no previous method has been successful;

- search for persons, including the missing.

More mobile, more flexible and better integrated into international criminal networks, organized criminals are now seeking, given the increasing pressure from law enforcement, to better penetrate the legal sphere in order to develop their illegal activities.

The advantages of the economic and financial spheres are obvious. There are no fingerprints, no DNA traces, no crime scene and no witness, so there is no evidence and therefore no conviction. However, as criminals have learned to rely on financial transactions and economic relations, the financial system and the general economic environment now provide concrete opportunities to fight organized criminals.

If the intrusion into the legitimate economy of modern criminal threats is clearly recognized, white-collar crimes remain difficult to investigate and criminals difficult to prosecute. Hence the growing gap between the evolution of modern criminals and the reaction of law enforcement agencies. Thus, there is a need to expand the capabilities and know-how of investigations.

EU countries have agreed to make financial investigations a fundamental component of all counter-terrorism investigations (revised EU Terrorist Financing Strategy). Discussions on the implementation of some international agreements (such as the UN Convention against Corruption, the Council of Europe Convention on Action against Crime or the G8 Marine Cocaine Action Plan) also emphasize the need to strengthen financial investigations and financial crime analysis at all stages of criminal investigations and prosecutions.

Despite the implementation of money laundering legislation, the results of convictions are unsatisfactory. The European Commission intends to support the 
integration of financial investigation and analysis of financial crimes, so that it becomes a standard part of the investigation, law enforcement techniques in all Member States in all cases of serious and organized crime (not just financial crimes). Based on the Report of the 5-th Round of MONEYVAL Mutual Evaluation, Ukraine's law enforcement agencies disagreed on the meaning of the term "financial investigation" - money laundering investigation, or investigation of other financial offenses, or investigation of cases related to illegal income from offenses. In addition, there are no general instructions on when to initiate a financial investigation and what its purpose is.

Conclusions. Thus, the implementation of international standards in national law in some way unifies the approaches to the investigation of complex crimes, which are often combined in a scheme, and allows the introduction of effective methods of investigating such crimes. According to the FATF Recommendations, financial investigations typically lead to the detection of other, previously unknown crimes, as well as assets that have been acquired for proceeds of crime and, as a result, may be subject to confiscation [10]. Taking into account international standards, Ukraine managed to build a preventive APC / FT and anti-corruption system. In the context of reforming the anti-corruption system, Ukraine has now formed a legal framework that generally meets international standards developed in international treaties and the practice of many foreign countries.

\section{References:}

1. Eduard Ivanov AML/CFT and Anti-Corruption Compliance Regulation: Two Parallel Roads. March 2018

2. International Standards on Combating Money Laundering and the Financing of Terrorism \& Proliferation

- the FATF Recommendations// 2012 https://www.fatf-
gafi.org/publications/fatfrecommendations/documents/internationalstandardsoncombatingmoneylaunderinga ndthefinancingofterrorismproliferation-thefatfrecommendations.html

3. United Nations Convention against Corruption//https://www.unodc.org/unodc/en/treaties/CAC/

4. UNCAC in a nutshell: A quick guide to the United Nations Convention against Corruption for embassy and donor agency staff//https://www.u4.no/publications/uncac-in-a-nutshell.pdf

5. Foreign Corrupt Practices Act//https://www.justice.gov/criminal-fraud/foreign-corrupt-practices-act

6. Bribery Act 2010//https://www.legislation.gov.uk/ukpga/2010/23/contents

7. Holmes, L. ed., 2010. Terrorism, Organized Crime and Corruption: Networks and Linkages. Cheltenham: Edward ElgarPublishing Ltd.

8. FATF, 2011. Laundering the Proceeds of corruption. FATF. Available at: http://www.fatfgafi.org/media/fatf/documents/reports/Laundering\%20the\%20Proceeds\%20of\%20Corruption.pdf

9. United Nations Convention against Corruption (full text)//https://www.unodc.org/documents/treaties/UNCAC/Publications/Convention/08-50026_E.pdf 10.International standards on combating money laundering and the financing of terrorism \& proliferation: The FATF Recommendations //https://www.fatfgafi.org/media/fatf/documents/recommendations/pdfs/FATF\%20Recommendations\%202012.pdf

11.Van Hoecke, M., 2015. Methodology of Comparative Legal Research. Law and Method, 2015 (4). Available at: http://www.lawandmethod.nl/tijdschrift/lawandmethod/2015/12/RENM-D-14-00001.pdf 12.History of Anti-Money Laundering Laws https://www.fincen.gov/history-anti-money-laundering-laws 13. Office of the Comptroller of the Currency. "Bank Secrecy Act (BSA)." Accessed July 31, 2020. https://www.occ.treas.gov/topics/supervision-and-examination/bsa/index-bsa.html 
14.Methodology for assessing technical compliance with the fatf recommendations and the effectiveness of AML/CFT systems//http://www.fatfgafi.org/media/fatf/documents/methodology/FATF\%20Methodology\%2022\%20Feb\%202013.pdf

15.The USA PATRIOT Act: Preserving Life and Liberty//https://www.justice.gov/archive/ll/highlights.htm 16.https://uk.wikipedia.org/wiki

17.UN General Assembly resolution on combating corruption of 12 December 1996//https://documents-ddsny.un.org/doc/UNDOC/GEN/N97/762/73/PDF/N9776273.pdf?OpenElement

18.UN Declaration against Corruption and Bribery in International Commercial Transactions//https://www.unodc.org/documents/commissions/CCPCJ/CCPCJ_Sessions/CCPCJ_11/ECN15-2002-06/E-CN15-2002-6_E.pdf

19.Guidelines for the effective implementation of the Code of Conduct for Law Enforcement Officials//https://www.ohchr.org/en/professionalinterest/pages/lawenforcementofficials.aspx

20.The International Code of Conduct for Officials//https://www.un.org/press/en/1996/19961031.gash3372.html

21.Criminal Law Convention on Corruption//https://rm.coe.int/168007f3f5

22.Civil Law Convention on Corruption//https://www.coe.int/en/web/conventions/full-list//conventions/treaty/174

23.Additional Protocol to the Criminal Law Convention on Corruption//https://www.coe.int/en/web/conventions/full-list/-/conventions/treaty/191

24.https://www.occ.treas.gov/topics/supervision-and-examination/bsa/index-bsa.html

25.Bray, J., 2017. Can companies really adopt a single global anti-corruption policy? FCPA Blog post, [blog] 28 June. Available at: http://www.fcpablog.com/blog/2017/6/28/john-bray-can-companies-reallyadopt-a-single-global-anti-co.html

26.Miller \& Chevalier, 2017. FCPA Spring Review 2017. [online] Available at: https://www.millerchevalier.com/publication/fcpa-spring-review-2017

27.IBA Anti-Corruption Committee, 2017. Anti-Corruption Law and Practice Report 2017: Innovation in Enforcement and Compliance IBA. Available at: https://www.ibanet.org/LPD/Criminal_Law_Section/AntiCorruption_Committee/Publications.aspx

Received: August 12, 2020 Approved: September 18, 2020 